Regular Research Article

\title{
Farmer fertilization practices of mature rubber plantations in Northeast Thailand during a period of low rubber prices
}

\author{
Supattra Kullawong ${ }^{1}$, Satit Aditto ${ }^{1}$, Bénédicte Chambon ${ }^{2}$, Arunee Promkhambut ${ }^{1, *}$ \\ 1 Khon Kaen University, Thailand \\ 2 CIRAD, France \\ * Correspondence author: arunee@kku.ac.th
}

\begin{abstract}
Since 2000, farmers in Northeast Thailand have planted more than 5,000 sq km of rubber on land previously devoted to agriculture. The expansion of rubber led to a significant increase in tree cover in Northeast Thailand. Rubber prices peaked in 2011 and since then farmers have had to adjust to lower prices. Little research has documented how farmers responded to low rubber prices. This paper seeks to describe how small-scale rubber farmers use fertilizer in a region that did not historically grow rubber during a period of low rubber prices. We collected data from structured interviews with 29 farmers in Subsomboon village in Khon Kaen province, Northeast Thailand. Most farmers reported that they reduced fertilizer costs by reducing the number of times they applied fertilizer, as well as changing to cheaper brands and/or using organic fertilizer. The majority of farmers still used large amounts of chemical fertilizers, either alone or in combination with commercial organic fertilizers with unknown nutrient contents. The $\mathrm{N}$ and $\mathrm{P}_{2} \mathrm{O}_{5}$ contents of the chemical fertilizer alone were consistent with national recommendations (82.0-137.6 kg N/ha/y and 33.3-97.7 kg $\left.\mathrm{P}_{2} \mathrm{O}_{5} / \mathrm{ha} / \mathrm{y}\right)$. Thai national recommendations for rubber, however, were developed for rubber plantations in traditional planting areas where rubber has been grown for over a century, and are considered by many experts to be high. The study's findings indicated that small scale rubber farmers would benefit from recommendations for fertilizer applications that respond to variations in rubber prices, while taking into account the diversity of individual household characteristics and goals. To optimize recommendations that sustain the growth and yield of rubber, limit the effects of environmental externalities, and maintain rubber's profitability, policymakers require detailed information on the diverse situations in which rubber is grown. This requires experimental research that tests a variety of fertilization practices under different biological and physical conditions.
\end{abstract}

Keywords: nutrient; smallholder; organic fertilizer; fertilizer intensity; Hevea brasiliensis; benefit; tree cover

\section{Introduction}

The most significant cause of global deforestation-defined as the reduction in forest canopy cover to $10 \%$ or less -is the conversion of forests to non-forest lands cover. In Thailand, rubber is not considered a forest tree (Royal Forest Department, n.d.), however, rubber plantations significantly increase tree cover particularly in the Northeast where $90 \%$ of new rubber plantations replaced annual crops such as sugarcane, cassava and rice (Tongkaemkaew, 2013; Chambon et al., 2016; Hurni \& Fox, 2018). A century after rubber plantations were first established in the southern part of Thailand, the Thai government introduced rubber to the Northeast, a non-traditional and marginal environment for the crop with the goals of improving local smallholder incomes, increasing tree cover, and freeing land in southern Thailand for oil palm plantations (Fox \& Castella, 2013; Thongpan, 2016). Thailand's Office of Rubber Replanting Aid Fund (ORRAF) began planting experimental rubber pilot projects in the Northeast in 1989. Beginning from a few volunteer farmers, the incentive of high rubber prices from the late 2000's through the early 2010's led to a rapid expansion of small-holder rubber plantations across the region.

In 2016, rubber plantations covered 564,304 ha, representing a source of income for 261,881 households in Northeast Thailand (Department of Agricultural Extension, 2016). With the increasing 
prices, rubber improved household incomes, education rates, and living conditions of both farm owners and hired laborers (Fox \& Castella, 2013; Tongkaemkaew \& Patanothai, 2013), and stimulated local economies in the region (Tongkaemkaew, 2013). However, after hitting record high prices in 2011, rubber prices have continuously declined. The Thai government has taken several measures to address this situation, including direct subsidies to rubber farmers and farmers' organizations, and market interventions since 2009. One strategy that has been recommended for farmers is to reduce their production costs, particularly fertilizer costs (Rubber Research Institute of Thailand, n.d.). To do so, some farmers have reduced the amount of chemical fertilizer used, switched at least partly to organic fertilizer, and even stopped applying fertilizer altogether (Neadkhun, 2017; Nicod, 2017).

Fertilizer and labor (for tapping and processing) are two major production costs in rubber farming (Viswanathan, 2008; Gohet et al., 2013; Burannasarn et al., 2015). Excessive use of fertilizer not only increases production cost but also impacts living organisms at all levels from genes and genomes to ecosystems, reshaping ecological and ultimately ecosystem processes (Guignard et al., 2017). While Thailand's recommended rates of fertilizer application are high compared to those of other countries, recent research has shown that farmers, particularly in the new rubber planting areas such as the Northeast, follow the recommendations and use a high quantity of fertilizer (Chambon et al., 2018). Chambon et al. (2018) argue that the main factor driving the intensive use of fertilizer is the relative lack of experience farmers have with rubber, causing them to depend heavily on extension agency recommendations. However, Chambon et al.'s study was conducted during a period when rubber prices were still relatively high (USD $2 / \mathrm{kg}$ ), which is a strong incentive for applying more fertilizer. There is a lack of research attempting to do a detailed analysis of farmer fertilization practices during periods of low rubber prices. Therefore, this study addresses one research question: how do small farmers that grow rubber adapt their fertilization practices in the context of low and decreasing rubber prices?

Chambon et al. (2018) reported that the fertilization practices of rubber farmers differ in different regions of Thailand due to farmers' varying levels of experience. They also found that supply of fertilizers, availability of fertilization recommendations, membership in rubber farmer groups, total landholding size, level of crop diversification, household income, and number of rubber cycles on the plot affected the intensity of fertilizer use by farmers. The study found different factors driving fertilizer application rates among farmers even in the same region. Considering previous findings, this study focuses on one village, investigating farmer choices under similar biophysical conditions, similar access to fertilizers, and similar recommendations for application rate, in order to understand the reasons behind farmers' fertilization practices at times of low rubber prices. We expect the results of this study to be useful for agronomists, extension officers, and policymakers as they consider different strategies for recommending fertilizer rates for rubber-producing family farms. We also expect the results of the study to provide strategies for managing small rubber plantations that are sustainable, maintain and increase household incomes, and enhance tree cover now and in the future.

\section{Materials and Methods}

\subsection{Selection of the case study village and farm sampling}

This study focuses on fertilizer management in mature rubber plots. Therefore, a main criterion for the selection of the study area was the presence of farms with mature rubber plantations. Secondary data from relevant organizations such as the Office of the Rubber Replanting Aid Fund (ORRAF; now the Rubber Authority of Thailand, RAOT), provincial and district Agricultural Extension Offices, and published literature were used as sources to identify long-established rubber planting areas in the province. According to the RAOT, the most concentrated and longest established rubber farming was in Doonsard sub-district, Kranuan district. Therefore, we chose this sub-district as our main study area. To control for the effects of biophysical, distance to the market, and access to 
places to buy fertilizers variables, we decided to select one village for data collection. After interviewing the District Agricultural Extension officers, the head of a Kranuan District rubber farmers' group, committees of Kranuan rubber farmer groups, members of Kranuan rubber farmer groups, and the heads of two or three villages within the sub-district, we chose Subsomboon village as our study site. Subsomboon had the oldest trees and highest percentage of mature rubber trees in the area.

We surveyed all households (76 households) in the village to identify rubber farmers, using a short questionnaire. Fifty-four households were rubber farmers with rubber plantations ranging in age from 1 to 25 years. We made extensive efforts to survey all rubber farmers. The first author, stayed in the village for a month to collect data but unfortunately we could not reach all farmers for two reasons. First some farmers were away from their plots throughout our survey, and second some farmers did not want to participate. These farmers posed a potential threat to the safety of the interviewer. Ultimately, we interviewed 45 of the 54 (83\%) households that grow rubber. To allow an analysis of returns from investment in fertilizer with no variation in yields due to the age of the rubber trees, we selected farmers who had at least one plot with 10-13 year old rubber trees. This age represented the majority of the rubber trees in the study area, where the rubber boom started in about 2004. Thirty-two farmers had rubber plots that met this criterion. However, three of these farmers were not included in the study due to unreliable data on rubber yields. Therefore, the final sample consisted of only 29 farmers.

\subsection{General context and the development of rubber farming in the study village}

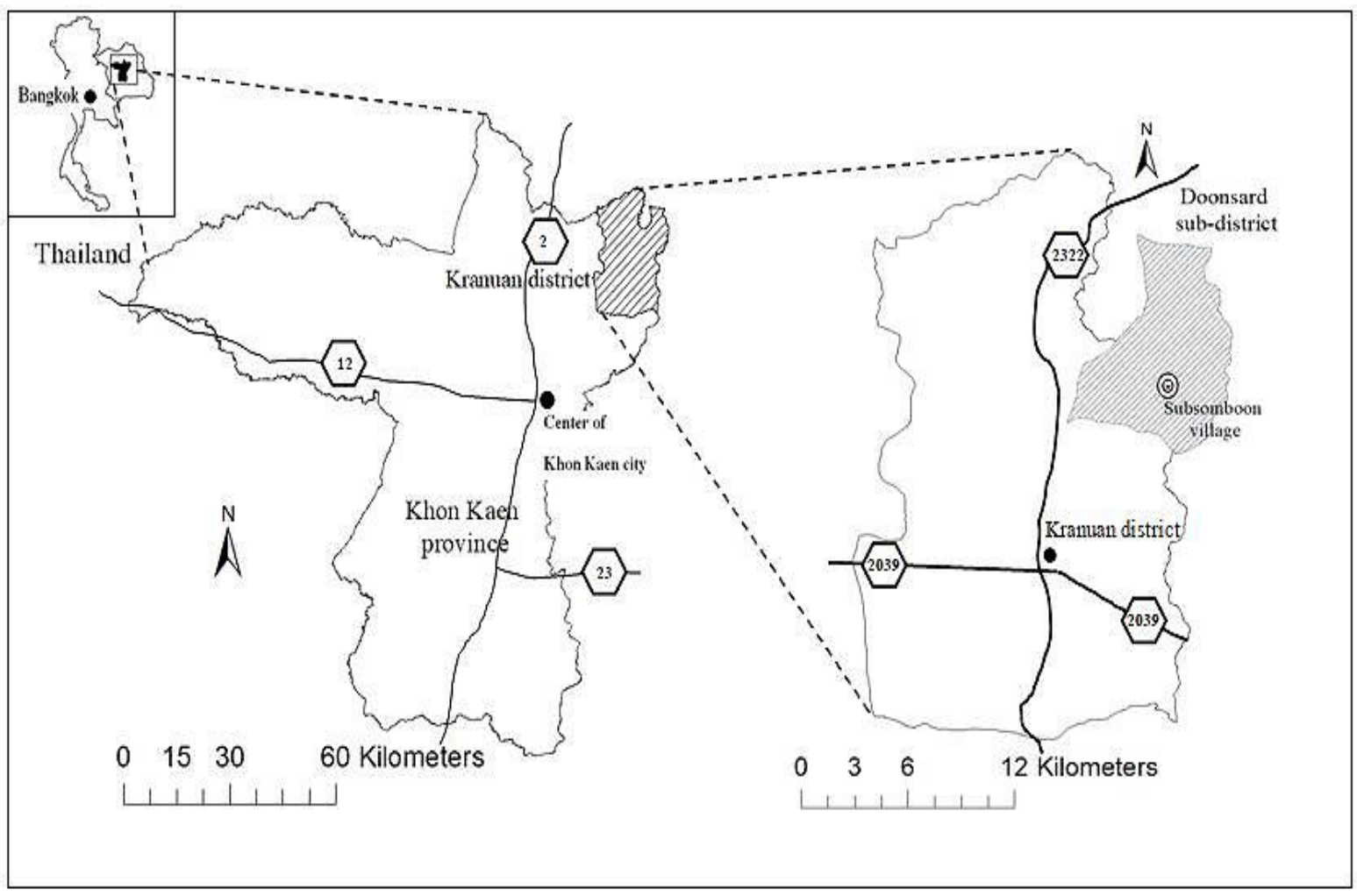

Figure 1. Map showing the location of the study site of Subsomboon village in Khon Kaen province.

Subsomboon village is located at 16047'05.99"N, 10308'29.94"E. It is about 16 kilometers north from Kranuan city and 70 kilometers from Khon Kaen city (Figure 1). The soil in the village is mostly sandy soil (Land Development Department, 2015). In 2016, the rainy season lasted from mid May to mid October. The rainy season in the area usually has a bimodal pattern, with the first peak in May and the second in September. The average annual rainfall is 1,663 $\mathrm{mm}$ (Doonsard Subdistrict 
Administrative Organization, 2016). The area of the village is about 2,300 rai (368 ha), with a total agricultural area of about 2,191 rai (350 ha). The village is located in undulating land and relies on rainfall for agriculture. There were 76 households and 251 people in the village (Doonsard Subdistrict Administrative Organization, 2016). Due to its setting in a National Reserve Forest, the government owns all the land. Farmers have the right to farm the land and can pass their land rights on to their children, but they cannot sell the land.

Data from key informants indicated that in 2016 , the farmers in the village grew rubber $(60 \%$ of total agricultural land), cassava and sugarcane (18\%), and fruit trees (2\%) in the uplands. In the lowland areas, land was devoted to lowland rice (10\%) (Figure 2). Some farmers raised cows, ducks, chickens, pigs, and vegetables (such as chilli), and maintained home gardens for home consumption and selling surplus produce. In the interviews, farmers reported that the high price of rubber in 2011 had encouraged some of them to turn lowland paddy fields into rubber plots.
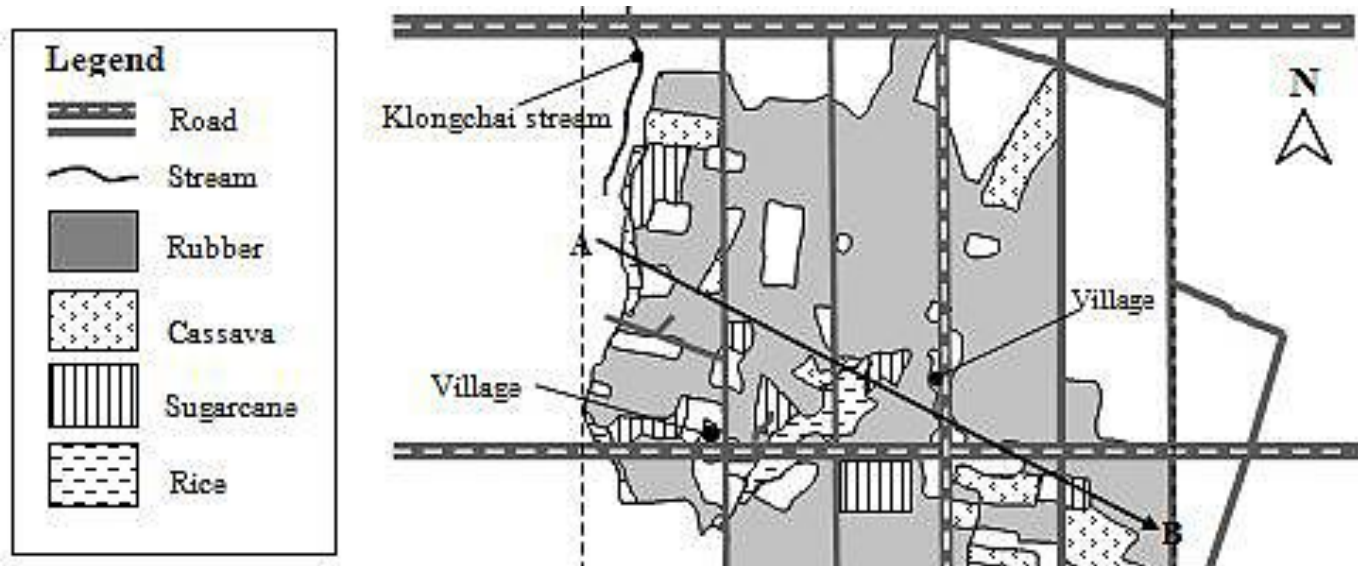

*Blank spaces include residences and unused lands

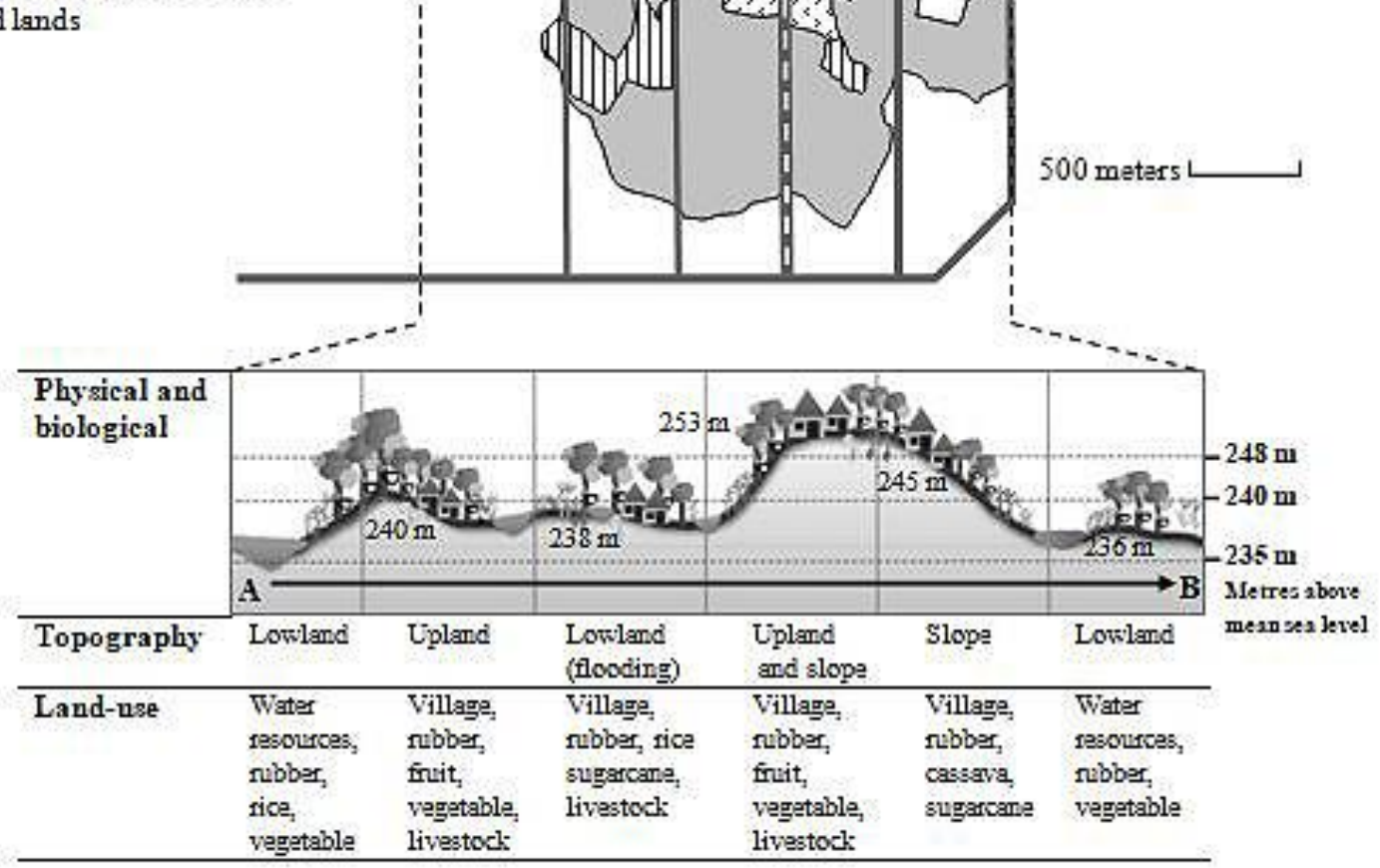

Figure 2. Land-use map, Subsomboon village, Doonsard sub-district, Kranuan district, Khon Kaen province. 
With the support of ORRAF, 10 farmers (21 ha) started planting rubber in Subsomboon in 1992. Before that, in the upland areas, the farmers grew kenaf (a fiber crop), and then cassava and sugarcane. When they began to grow rubber, ORRAF provided inputs (i.e., RRIM 600 rubber saplings and fertilizer) and technical knowledge. Therefore, most of the rubber farmers' agricultural practices followed the recommendations of ORRAF. In 2004, the area devoted to rubber started to increase, reaching its maximum in 2011 with 121.6 ha of rubber trees. During this time, most of the farmers invested their own resources, although the government supported some farmers (i.e., budget for land preparation, rubber saplings, and chemical fertilizers). Household labors provided the labor force, but some households hired local and foreign laborers from Laos, especially for tapping. Farmers allotted a portion of the product to hired laborers to pay for their services (share cropping). Farmers no longer only followed ORRAF recommendations but also the advice of relatives and other farmers. During this time, rubber was booming in the study area. Many local buying points emerged (i.e., private collectors, a local rubber co-operative, and farmers' groups such as the Kranuan District rubber farmers' group). Rubber became the main source of these farmers' income.

The price of rubber has declined since 2012 onward, and consequently some farmers have changed from producing rubber sheets (a high labor-demand product) to producing cup coagulum (i.e., the latex that coagulates in cups attached to the rubber tree and collected when the cup is full or when the farmers want to sell). During our survey, in 2016, all of the farmers had switched entirely to cup coagulum. Since 2012, farmers have planted few new rubber trees because of the decreasing price of rubber, the limited land availability, and the fact that ORRAF no longer subsidizes rubber planting. Over the past several decades, many young people from the Northeast have migrated to find labor in Bangkok, elsewhere in Thailand, or abroad. During the period of high rubber prices, some laborers returned to the study village to work on the rubber plantations, both as hired labor and as farm owners. When the price of rubber decreased, however, many of the hired laborers, both foreigners and local returnees, left the area, although some remained in the village to work both on- and off-farm (Kullawong et al., 2018).

\subsection{Data collection}

We conducted the survey between September 2016 and September 2018 and emphasized agricultural practices in the 2016-2017 crop year. We interviewed the head of each farm by using a structured questionnaire with three sets of questions. The first part of the questionnaire aimed to understand farmers' and farms' characteristics as they may be related to farmers' fertilization practices. The second part consisted of open-ended questions designed to describe the farmer's practices at all steps of rubber production during the trees' maturing stage, focusing on fertilizer and farmers' rationale for choosing particular fertilizer management practices, as well as their perceptions of the effects of fertilizer use on crop growth, yield, and production costs. The third part collected economic data on fertilizer inputs and sources of knowledge for fertilizer use. Finally, in order to calculate returns from fertilizer in each plot, the yield of rubber in a year was estimated following a method that one of the authors had previously used for many research projects:

Yield of rubber per ha per year $=$

$\Sigma[$ (Number of tapping days in rainy season (days)x yield of rubber per day in rainy season $(\mathrm{kg}))+$

(Number of tapping days in winter season (days)x yield of rubber per day in winter season (kg)) +

(Number of tapping days in summer season (days)x yield of rubber per day in summer season (kg))]xDRC(0.6) (1)

We used 0.6 as the value for dry rubber content (DRC), which corresponds to the average DRC of cup coagulum in the country (Agricultural Research Development Agency, n.d.). This yield was further used to calculate gross income from rubber by multiplying yield by cup coagulum price, using the average of the prices reported by a total of 29 farmers.

Total production cash cost, except family labor costs and fuel costs (which form a small part of total costs), was calculated as the variable cost. Finally, gross added value was calculated as gross income minus total production cost. 


\subsection{Data analysis}

We entered and analyzed all data in Excel. We classified fertilization practices by adapting the typology developed by Chambon et al. (2018). We used rate of fertilizer application instead of nutrient content as a criterion, due to the high number of farmers in our sample who used organic fertilizer with unknown nutrient content, as well as a lack of consistency in the chemical fertilizers they used and in the information about its nutrient content. As shown in Table 1, four aspects of fertilizer management were used as criteria to classify the farmers' practices as high, medium, or low intensity: rate of use of chemical fertilizer (i.e., amount used each year), rate of use of organic fertilizer (i.e., amount used per year), frequency of fertilizer application, and method of application. Rate of chemical fertilizer use has four levels: non-use, low intensity $=6.25-250.00 \mathrm{~kg} / \mathrm{ha} /$ year, medium intensity $=256.25-625.00 \mathrm{~kg} / \mathrm{ha} / \mathrm{year}$, and high intensity $=631.25-937.50 \mathrm{~kg} / \mathrm{ha} /$ year. Rate of organic fertilizer use also has four levels: non-use, low intensity $=6.25-312.50 \mathrm{~kg} / \mathrm{ha} / \mathrm{year}$, medium intensity $=318.75-833.75 \mathrm{~kg} / \mathrm{ha} /$ year, and high intensity $=834.37-1,250.00 \mathrm{~kg} / \mathrm{ha} / \mathrm{year}$. Frequency of fertilizer application has two levels, following a Rubber Research Institute of Thailand (2011) criterion: high if applied two or more times a year, low if applied once or not at all. Methods of application are either incorporation into the soil, which is considered a high intensity practice, and banding or broadcasting, which are considered low intensity practices. Regarding organic fertilizer, all farmers who used it reported using commercial organic fertilizer pellets. Two farmers tried soil amendments and bio-fertilizers; however, due to the small number, we did not include this practice. Further, in order to better characterize fertilization practices, N-P2O5-K2O contents were calculated for those farmers $(n=18)$ who could remember the formula of the chemical fertilizer used.

Table 1. Intensity of fertilizer practices based on the combination of type of fertilizer, rate of use, frequency of application, and method of application in 10-13 year old rubber plots for the 2016-17 crop year $(n=29)$

\begin{tabular}{|c|c|}
\hline Fertilizer practices a) & Indicators ${ }^{b)}$ \\
\hline High intensity & $\begin{array}{l}\text { 1) High rate of use of chemical fertilizer only, or combined with low-medium } \\
\text { rate of use of organic fertilizer pellets; applied } \geq 2 \text { times/year; incorporated } \\
\text { into the soil }\end{array}$ \\
\hline Medium intensity & $\begin{array}{l}\text { 1) Medium rate of use of chemical fertilizer only (or combined with soil } \\
\text { amendments), or medium-high rate of use of organic fertilizer pellets; applied } \\
\geq 2 \text { times/year; incorporated into the soil or banding/broadcasting } \\
\text { 2) Medium rate of use of chemical fertilizer only; applied } 1 \text { time/year; } \\
\text { incorporated into the soil } \\
\text { 3) Low rate of use of chemical fertilizer combined with medium rate of use of } \\
\text { organic fertilizer pellets; applied } \geq 2 \text { times/year; incorporated into the soil or } \\
\text { banding/broadcasting }\end{array}$ \\
\hline & $\begin{array}{l}\text { 4) Medium-high rate of use of organic fertilizer pellets; applied } \geq 2 \\
\text { times/year; incorporated into the soil or banding/broadcasting }\end{array}$ \\
\hline Low intensity & $\begin{array}{l}\text { 1) Low rate of use of chemical fertilizer only or combined with low rate of use } \\
\text { of organic fertilizer pellets; applied 1-2 times/year; incorporated into the soil } \\
\text { or banding/broadcasting } \\
\text { 2) Low rate of use of organic fertilizer pellets; applied } 1 \text { time/year; } \\
\text { banding/broadcasting }\end{array}$ \\
\hline
\end{tabular}

a) Identified by the authors.

${ }^{b)}$ Adapted from Chambon et al. (2018). 


\section{Results}

\subsection{Farmers' fertilizer practices during periods of low rubber prices}

In the interviews with rubber farmers $(n=29), 66 \%$ of the farmers reported that they changed fertilizer practices, one way or another, to reduce their costs. Most farmers changed to cheaper chemical fertilizers ( 14 farmers), changed from chemical fertilizer only to a combination of chemical and organic fertilizer (10 farmers), and/or changed from organic fertilizer to a cheaper chemical fertilizer (10 farmers). The latter group mentioned that, at the same cost, chemical fertilizer was better than organic fertilizer for growth and yield stimulation. Other methods were also applied by some farmers such as changing from chemical fertilizer only to organic only, or to a combination of chemical fertilizer with bio-fertilizer and dolomite, or simply applying less chemical fertilizer. It was surprising that one farmer increased fertilization frequency while using the same amount of fertilizer, and one also changed application methods from the high-cost and timeconsuming method of incorporating it into the soil, to the quicker and lower-cost method of broadcasting. Ten farmers reported that they had never changed their practices due to using low amounts of fertilizer even before the rubber price decrease; six of these ten used a combination of chemical and organic fertilizers (Table 2).

Table 2. Changes in farmers' fertilizer practices due to low rubber prices

\begin{tabular}{lc}
\hline \multicolumn{1}{c}{ Fertilizer practices ${ }^{\text {a) }}$} & Number of farmers \\
\hline No change & 10 \\
Change from chemical fertilizer to organic fertilizer pellets & 8 \\
Change to cheaper chemical fertilizer & 14 \\
Change from organic fertilizer to cheaper chemical fertilizer & 10 \\
$\begin{array}{l}\text { Decrease amount of chemical fertilizer } \\
\text { Change from chemical fertilizer to combination of chemical } \\
\text { fertilizer and organic fertilizer pellets }\end{array}$ & 3 \\
Change from chemical fertilizer to combination of chemical & 10 \\
fertilizer and soil amendments & 2 \\
$\begin{array}{l}\text { Increase frequency of fertilizer application but no change in } \\
\text { amount of fertilizer } \\
\text { Change application method from incorporating into the soil } \\
\text { to broadcasting }\end{array}$ & 1 \\
\hline
\end{tabular}

a) Some farmers used multiple practices.

Although most of the farmers in the study area changed their fertilizer practices to reduce costs, the intensity of their fertilizer practices differed among them. Most farmers (21; 72.4\%), used medium intensity practices, four farmers $(13.8 \%)$ used high intensity practices, and another four farmers (13.8\%) used low intensity practices.

Among those who used high intensity practices (H group), chemical fertilizer represents $67 \%$ of all fertilizers used. On average, these farmers used chemical fertilizer at the rate of $901.6 \mathrm{~kg} / \mathrm{ha} / \mathrm{year}$, which is double the mean for all farmers $(473.2 \mathrm{~kg} / \mathrm{ha} /$ year $)$ and half the mean for organic fertilizer $(440.6 \mathrm{~kg} / \mathrm{ha} /$ year) (Figure 3). Nitrogen use, calculated from their chemical fertilizer use, by farmers in the $\mathrm{H}$ group was $137.6 \mathrm{~kg} / \mathrm{ha} / \mathrm{y}$, which is 1.5 times higher than the overall average (Figure 4). Farmers in this group mostly applied fertilizer two times a year by incorporating fertilizer into the soil.

Farmers in the medium fertilizer intensity group (M group) used the highest amount of organic fertilizer, which comprised of $63 \%$ of all the fertilizer they used, $692.8 \mathrm{~kg} / \mathrm{ha} / \mathrm{y}$. Nevertheless, the $\mathrm{M}$ group used about the same amount of chemical fertilizer as the overall mean, $408.4 \mathrm{~kg} / \mathrm{ha} / \mathrm{y}$ (Figure 3), with an $\mathrm{N}$ rate of $82 \mathrm{~kg} / \mathrm{ha} / \mathrm{y}$ (Figure 4). In addition, most $\mathrm{M}$ group farmers applied fertilizer two 
times a year, with various methods; that is, incorporating it into the soil or using banding or broadcasting methods.

Farmers in the low intensity group (L group), applied the lowest amount of chemical fertilizers among the three groups. These farmers still used relatively high amounts of chemical fertilizer, an amount equal to $45 \%$ of all of the fertilizer they used $(226 \mathrm{~kg} / \mathrm{ha} / \mathrm{y})$. However, they still had the lowest amount of $\mathrm{N}(34.8 \mathrm{~kg} / \mathrm{ha} / \mathrm{y})$ from chemical fertilizer among the three groups (Figure 4). Among armers in this group, $55 \%$ of the fertilizer they applied was organic, but the total $(281.3$ $\mathrm{kg} / \mathrm{ha} / \mathrm{y}$ ) was still the lowest amount of organic fertilizer applied among the three groups (Figure 3). On average, farmers in the L group fertilized 1.5 times/year, and applied it with banding or broadcasting methods rather than incorporating it into the soil.

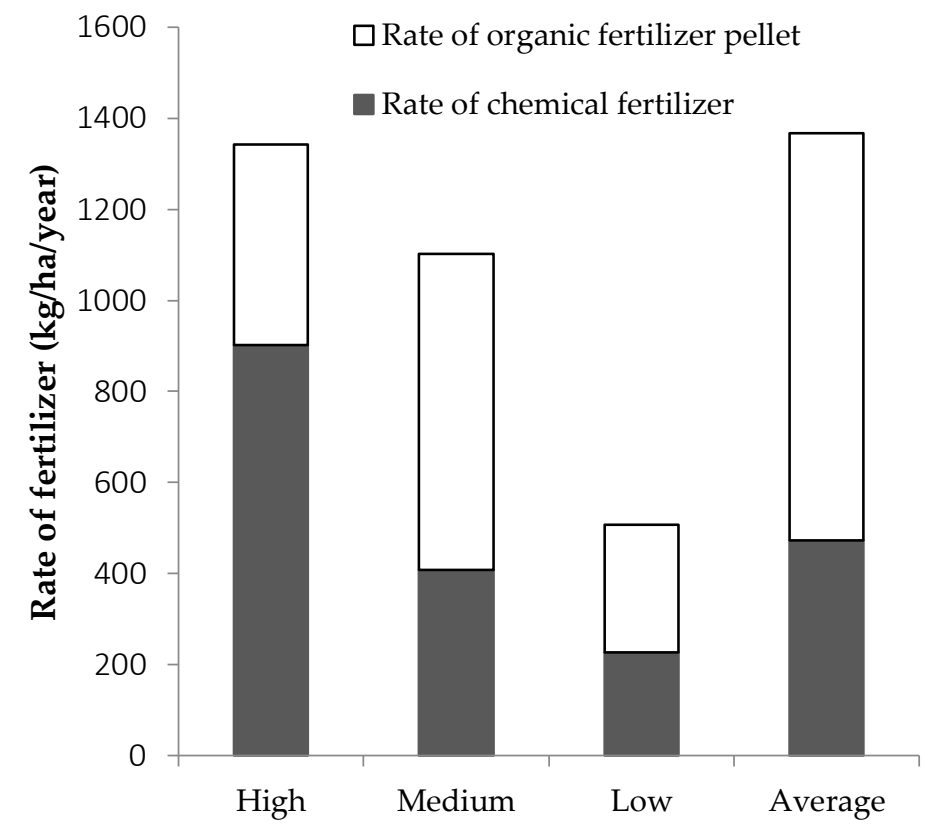

Figure 3. Rate of fertilizer (chemical and organic) use at three intensity levels of fertilizer practices and for the whole sample in the study site $(\mathrm{kg} / \mathrm{ha} /$ year)
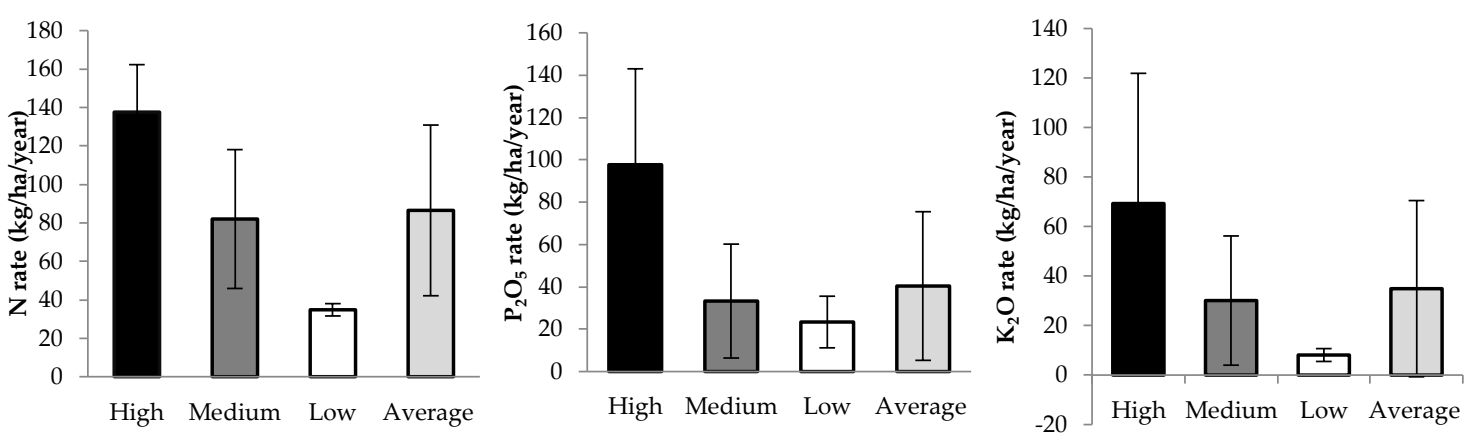

Figure 4. Rates of $\mathrm{N}, \mathrm{P}_{2} \mathrm{O}_{5}$, and $\mathrm{K}_{2} \mathrm{O}(\mathrm{kg} / \mathrm{ha} / \mathrm{year})$ applied in chemical fertilizer at each intensity level of fertilizer practices and for the whole sample in the study site $(\mathrm{kg} / \mathrm{ha} / \mathrm{year})$. Vertical bars indicate standard deviations.

\subsection{Fertilizer cost and gross income in the three fertilization intensity groups}

As expected, the high intensity group had the highest fertilizer costs, with an average of USD $552.4 / \mathrm{ha} / \mathrm{y}$. Fertilizer costs accounted for $50 \%$ of their total production cost (Table 3 ). The medium intensity group also had relatively high costs at an average of USD $349.2 / \mathrm{ha} / \mathrm{y}$, or $45 \%$ of their total 
production cost. For this group, the cost of organic fertilizer was a significant part, $65 \%$, of their total fertilizer costs due to the high amount of organic fertilizer they used (Figure 5). The low intensity group had the lowest costs at USD 151.2/ha/y on average, which was about a quarter (24\%) of their total production cost (i.e., about half the proportion of the high intensity group's fertilizer cost to total production cost) (Table 3 ). The $\mathrm{H}$ group also had the highest labor costs due to their practice of incorporating fertilizer into the soil, representing $14 \%$ of their total fertilizer costs. The $L$ group had the next highest labor costs ( $11 \%$ of total fertilizer cost) among the three groups, due to one farmer who applied fertilizer by incorporating it into the soil; this farmer did so to prevent erosion as the plot was on a slope. For farmers in the M group, by comparison, only $3 \%$ of their labor costs came from fertilizer application (Table 3).

Table 3. Cash cost of fertilizer management, gross income, and gross added value of rubber production at three intensity levels of fertilizer practices in 10-13 year old rubber plots for the 2016-17 crop year $(n=29)$

\begin{tabular}{|c|c|c|c|c|c|c|c|c|}
\hline \multirow[t]{3}{*}{ Items } & \multirow{2}{*}{\multicolumn{2}{|c|}{$\begin{array}{c}\text { Total sample } \\
\begin{array}{c}(n=29) \\
100 \%\end{array}\end{array}$}} & \multicolumn{6}{|c|}{ Intensity of fertilizer practices } \\
\hline & & & \multicolumn{2}{|c|}{$\begin{array}{c}\text { High } \\
(n=4) \\
13.8 \%\end{array}$} & \multicolumn{3}{|c|}{$\begin{array}{c}\text { Medium } \\
(n=21) \\
72.4 \%\end{array}$} & \multirow{2}{*}{$\begin{array}{r}\begin{array}{c}\text { Low } \\
(n=4)\end{array} \\
13.8 \% \\
\text { SD }\end{array}$} \\
\hline & Average & SD & Average & SD & Average & SD & Average & \\
\hline \multicolumn{9}{|l|}{ Costs } \\
\hline $\begin{array}{l}\text { Total fertilizer cost } \\
\text { (USD/ha/year) }\end{array}$ & 360.4 & 187.9 & 552.4 & 48.8 & 349.2 & 172.3 & 151.2 & 72.9 \\
\hline $\begin{array}{l}\text { Cost of fertilizer } \\
\text { (USD/ha/year) }\end{array}$ & 335.9 & 160.1 & 526.6 & 46.3 & 337.9 & 140.7 & 134.6 & 51.4 \\
\hline $\begin{array}{l}\text { Cost of hired labor } \\
\text { (USD/ha/year) }\end{array}$ & 24.5 & $27.8^{b)}$ & 25.8 & 2.5 & 11.3 & $31.6^{b)}$ & 16.6 & 21.5 \\
\hline $\begin{array}{l}\text { Total production cost a) } \\
\text { (USD/ha/year) }\end{array}$ & 770.9 & 450.2 & $1,053.6$ & 537.1 & 759 & 329 & 550.8 & $636.1^{b)}$ \\
\hline $\begin{array}{l}\% \text { of fertilizer cost to total } \\
\text { production }\end{array}$ & 43.6 & & 50 & & 44.5 & & 24.4 & \\
\hline $\begin{array}{l}\text { Gross income } \\
\text { (USD/ha/year) }\end{array}$ & $2,245.1$ & 567 & $2,249.6$ & 818 & $2,187.9$ & 518.9 & $2,540.9$ & 630 \\
\hline $\begin{array}{l}\text { Gross added value } \\
\text { (USD/ha/year) }\end{array}$ & $1,474.2$ & 116.8 & 1,196 & 280.9 & $1,428.9$ & 189.9 & $1,990.1$ & 4.3 \\
\hline
\end{tabular}

a) Not including family labor costs and fuel costs.

b)SD is high due to a wide range within the group.

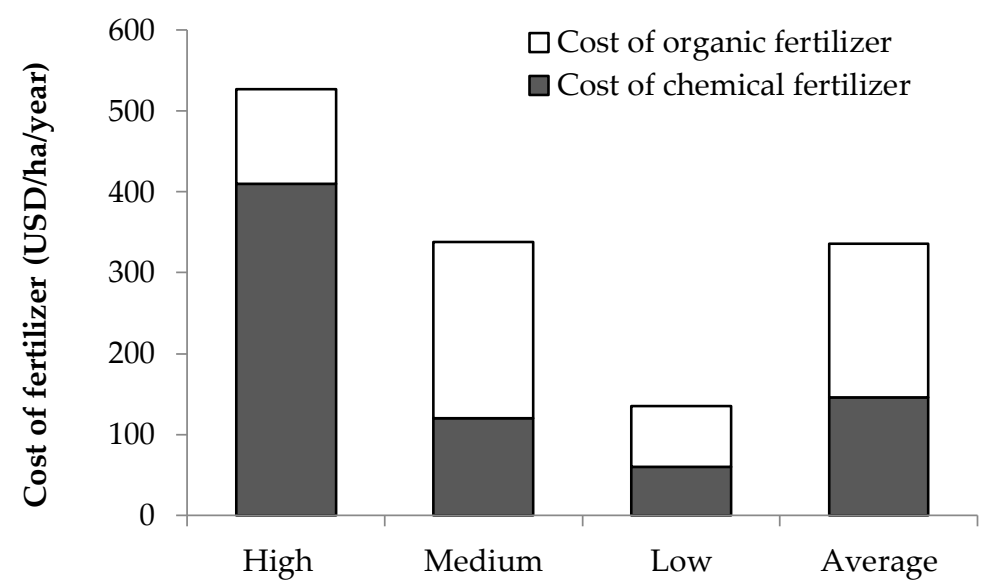

Figure 5. Cost of fertilizer (chemical and organic) at three intensity levels of fertilizer practices and for the whole sample in the study site (USD/ha/year) 
It is interesting to note that the $\mathrm{H}$ and $\mathrm{M}$ groups had similar gross incomes, USD 2,249.6 and $2,187.9 / \mathrm{ha} / \mathrm{y}$ respectively, while the $\mathrm{L}$ group had the highest gross income (USD 2,540.9 /ha/y). The $\mathrm{L}$ group also had the highest gross added value, USD 1,990.1/h/y (Table 3). Considering the cost of fertilizer management relative to total household income, we found that, as expected, the $\mathrm{H}$ group had the highest ratio of total fertilizer cost to total household income, $22 \%$. The ratio of total fertilizer cost to total household income was $11 \%$ for the $M$ group, and $2 \%$ for the $L$ group (data not shown).

\subsection{Characteristics of farmers and farm households in the three fertilization intensity groups}

We present descriptive statistics about the head of the household and household characteristics in Table 4. Due to the diversity of the farmers in the medium and low intensity practices groups, we divided the farmers in each of these groups into two sub-groups (M1, M2, L1, L2) to reflect different household conditions among farming households that made similar choices regarding fertilization practices. The main criterion used for these sub-groupings is the type of labor used on the farm: family labor (M1, L1) or permanent hired labor, i.e., share income tappers (M2, L2).

The average age of the rubber farm owners was 56 years old and lived in a household of 4.4 people. On average their experiences growing rubber or working on rubber plantations was quite similar in all groups (12-14.7 years) except M2 (18 years), where some farmers had worked on rubber plantations in other areas.

All farmers in $H, M 1, M 2$, and $L 2$, and all farmers except one in $L 1$, were currently members of one local and/or two district-level rubber farmer organizations. The benefits of belonging to these organizations included the ability to obtain credit for buying fertilizer and, cooperating together to sell their products at auction for higher prices than if they sold as individuals

Not all farmers attended agricultural trainings or meetings every year; attendance varied among the farmers within each group. The $H, M 1$, and $M 2$ groups showed relatively high participation in such trainings and meetings, ranging from two to three times within a five year period (2012-2016). The lowest participation was found in both L1 and L2; some farmers in these groups mentioned that they had no time to join trainings. The farmers who did attend such events reported that the trainings rarely focused on fertilization practices, instead covering topics such as adding value in the production of rubber cup lumps or latex, diversification in rubber plots, and how to use acid for making cup lump rubber.

The average size of total agricultural land holdings was 4.7 ha. Rubber was the major crop for most of the farmers in the sample: on average, each household had 4 ha of rubber. The high intensity group's plots were, on average, of medium size ( $4.5 \mathrm{ha}$ ), but rubber plantation was their major land use with relatively little crop diversification. 
Table 4. Characteristics of rubber farmers (heads of household) and their households in the study area $(n=29)$

Characteristics of rubber farmers and households

\begin{tabular}{|c|c|c|c|c|c|c|c|c|c|c|c|c|}
\hline \multirow[t]{3}{*}{ Housentios } & \multirow{2}{*}{\multicolumn{2}{|c|}{$(n=29)$}} & \multirow{2}{*}{\multicolumn{2}{|c|}{$(n=4)$}} & \multicolumn{4}{|c|}{ Iviearum } & \multicolumn{4}{|c|}{ Low } \\
\hline & & & & & \multicolumn{2}{|c|}{ M1 $(n=17)$} & \multicolumn{2}{|c|}{$M 2(n=4)$} & & $\mathrm{L} 1(\mathrm{n}=3)$ & $\mathrm{L} 2(\mathrm{n}=1)$ & \multirow[b]{2}{*}{ SD } \\
\hline & Average & SD & Average & SD & Average & SD & Average & SD & Average & SD & Average & \\
\hline Age of rubber farmer (years) & 56.2 & 12.1 & 64.5 & 5.1 & 50.6 & 11.9 & 65.3 & 7.4 & 64 & 10.5 & 60 & NA \\
\hline \multicolumn{13}{|l|}{ Gender of rubber farmer (\%) } \\
\hline Female & 48.3 & & 25 & & 52.9 & & 50 & & 33.3 & & 0 & \\
\hline Male & 51.1 & & 75 & & 47.1 & & 50 & & 66.7 & & 100 & \\
\hline \multicolumn{13}{|l|}{ Educational attainment (\%) } \\
\hline Elementary & 79.3 & & 100 & & 76.5 & & 50 & & 75 & & 100 & \\
\hline Secondary & 13.8 & & 0 & & 11.8 & & 50 & & 25 & & 0 & \\
\hline Tertiary & 6.9 & & 0 & & 11.8 & & 0 & & 0 & & 0 & \\
\hline Years of rubber farming experience & 13.8 & 4.8 & 13.3 & 9 & 12.7 & 2.3 & 18.5 & 7.5 & 14.7 & 4.6 & 12 & NA \\
\hline $\begin{array}{l}\text { Member of rubber farmer groups/ co- } \\
\text { operatives (\%) }\end{array}$ & 93.1 & & 100 & & 100 & & 100 & & 66.7 & & 100 & \\
\hline Number of trainings in last 5 years & 2.2 & 2.8 & 2 & 2.2 & 2.4 & $2.7^{\text {a) }}$ & 3.3 & $4.7^{\text {a) }}$ & 0.7 & $1.2^{\text {a) }}$ & 0 & 0 \\
\hline \multicolumn{13}{|l|}{ Source of fertilizer information (\%) } \\
\hline Only salesman & 75.9 & & 25 & & 76.5 & & 100 & & 100 & & 100 & \\
\hline Salesman and co-operative & 3.4 & & 0 & & 5.9 & & 0 & & 0 & & 0 & \\
\hline Salesman and rubber farmer group & 6.9 & & 50 & & 0 & & 0 & & 0 & & 0 & \\
\hline Salesman and relatives & 3.4 & & 0 & & 5.9 & & 0 & & 0 & & 0 & \\
\hline $\begin{array}{l}\text { Salesman, rubber farmer group, and } \\
\text { co-operative }\end{array}$ & 3.4 & & 25 & & 0 & & 0 & & 0 & & 0 & \\
\hline Only co-operative & 3.4 & & 0 & & 5.9 & & 0 & & 0 & & 0 & \\
\hline Other farmers & 3.4 & & 0 & & 5.9 & & 0 & & 0 & & 0 & \\
\hline
\end{tabular}

Other

Note. NA: not applicable. 
Table 4. Characteristics of rubber farmers (heads of household) and households in the study area $(n=29)$ (cont.)

\begin{tabular}{|c|c|c|c|c|c|c|c|c|c|c|c|c|}
\hline \multirow{4}{*}{$\begin{array}{l}\text { Characteristics of rubber } \\
\text { farmers and households }\end{array}$} & \multirow{3}{*}{\multicolumn{2}{|c|}{$\begin{array}{l}\text { Rubber farmer } \\
\qquad(n=29)\end{array}$}} & \multicolumn{10}{|c|}{ Intensity of fertilizer practices } \\
\hline & & & \multirow{2}{*}{\multicolumn{2}{|c|}{$\begin{array}{l}\text { High } \\
(n=4)\end{array}$}} & \multicolumn{4}{|c|}{ Medium } & \multicolumn{4}{|c|}{ Low } \\
\hline & & & & & \multicolumn{2}{|c|}{ M1 $(n=17)$} & \multicolumn{2}{|l|}{$M 2(n=4)$} & \multicolumn{2}{|c|}{$\operatorname{L1}(n=3)$} & \multicolumn{2}{|l|}{$\operatorname{L2}(n=1)$} \\
\hline & Average & SD & Average & SD & Average & SD & Average & SD & Average & SD & Average & SD \\
\hline $\begin{array}{l}\text { Number of household } \\
\text { members } \\
\text { (persons/household) }\end{array}$ & 4.4 & 1.4 & 3.7 & 1.5 & 4.5 & 1.4 & 4.5 & 1.3 & 5.0 & 1.0 & 3.0 & NA \\
\hline $\begin{array}{l}\text { Number of agricultural } \\
\text { laborers (persons/hh) }\end{array}$ & 2.4 & 1.1 & 2.5 & 1.7 & 2.4 & 0.9 & 1.5 & 0.6 & 3.7 & 1.2 & 1.0 & NA \\
\hline $\begin{array}{l}\text { Size of agricultural land } \\
\text { holding (ha/hh) }\end{array}$ & 4.8 & 3.4 & 4.7 & 3.2 & 4.1 & 2.2 & 7.2 & 8.8 & 2.2 & 1.0 & 17 & NA \\
\hline $\begin{array}{l}\text { Size of rubber area } \\
\text { (ha/hh) }\end{array}$ & 4.0 & 3.0 & 4.5 & 3.0 & 3.2 & 1.9 & 5.8 & 1.0 & 0.6 & 0.6 & 15.4 & NA \\
\hline $\begin{array}{l}\text { Number of rubber plots } \\
\text { (plot/hh) }\end{array}$ & 1.8 & 1.1 & 2.0 & 1.2 & 1.6 & 0.9 & 2.3 & 1.3 & 1.0 & 0 & 5.0 & NA \\
\hline $\begin{array}{l}\text { Ownership of farm } \\
\text { machinery (\%) }\end{array}$ & 69 & & 50 & & 76.5 & & 50 & & 100 & & 0 & \\
\hline $\begin{array}{l}\text { Total annual household } \\
\text { income (USD/hh/year) }\end{array}$ & $11,528.9$ & $11,777,1^{\text {a) }}$ & $9,577.1$ & 2,690 & $10,233.4$ & $9,144.6$ & $11,676.5$ & $3,965.5$ & $6,720.2$ & 1,441 & $60,317.1$ & NA \\
\hline $\begin{array}{l}\text { Total income from rubber; } \\
\text { plot age 10-13 years } \\
\text { (USD/hh/year) }\end{array}$ & $6,263.2$ & $3,868.1$ & $7,106.1$ & $2,030.8$ & $5,731.5$ & 3,841 & 6,959 & $3,438.5$ & $3,858.2$ & 1,756 & 16,360 & NA \\
\hline $\begin{array}{l}\% \text { of income from rubber; } \\
\text { plot age } 10-13 \text { years }\end{array}$ & $54.3 \%$ & & $74.2 \%$ & & $56 \%$ & & $59.6 \%$ & & $57.4 \%$ & & $21.7 \%$ & \\
\hline $\begin{array}{l}\text { Total on-farm income } \\
\text { (USD/hh) }\end{array}$ & $7,495.9$ & $5,399.5$ & $7,243.6$ & $2,272.5$ & $6,532.3$ & $3,970.4$ & $9,019.7$ & $2,881.2$ & 4,136 & $1,954.2$ & $28,870.5$ & NA \\
\hline $\begin{array}{l}\% \text { of total on-farm income } \\
\text { to total annual household } \\
\text { income }\end{array}$ & $65 \%$ & & $75.6 \%$ & & $63.8 \%$ & & $77.2 \%$ & & $61.5 \%$ & & $47.9 \%$ & \\
\hline $\begin{array}{l}\text { Total non-farm income } \\
\text { (USD/hh) }\end{array}$ & 4,177 & $7,554.6^{\text {a) }}$ & $2,333,5$ & $4,037.7^{\text {a) }}$ & $3,665.9$ & $6,816.7$ a) & $2,004.7$ & $1,602.6$ & $2,626.8$ & $1,207.7$ & $31,446.5$ & NA \\
\hline $\begin{array}{l}\% \text { of total non-farm } \\
\text { income to total annual } \\
\text { household income }\end{array}$ & $36.2 \%$ & & $24.4 \%$ & & $35.8 \%$ & & $17.2 \%$ & & $39.1 \%$ & & $52.1 \%$ & \\
\hline
\end{tabular}

household income

a) $\mathrm{SD}$ is high due to the wide range of the data within the group.

Note. NA: not applicable, hh: household 
Households in the M1 and M2 groups had different land use practices. The average total landholding area in M2 (7.2 ha) was much higher than in M1 (4.1 ha). Households in M1 also had smaller rubber areas (3.2 ha) than those in M2 (5.8 ha). However, M1 farmers had greater crop diversification on their land, growing cassava, sugarcane, rice, and vegetables, while $M 2$ farmers grew, besides rubber, mainly rice and vegetables. This difference indicates that the M1 households still possessed other accessible upland areas (Table 4).

Rubber plantations covered one third of the total land area of the L1 group, which had the smallest rubber areas ( $0.6 \mathrm{ha})$, but dedicated other parts of their land to rice and cassava. For the single $\mathrm{L} 2$ household, rubber was the only agricultural activity. This household also had the largest rubber area (15.4 ha) and the highest plot number, five plots, while farmers in the other groups had two plots on average, except for those in the L1 group, who averaged one plot (Table 4). The L2 household rented out some of its land rather than cultivating it, indicating land accumulation in this household.

The average total annual household income in this study was USD 11,529. All groups of households except $L 1$ and $L 2$, had incomes in a similar range (USD 9,577-11,676). In contrast, L1 had the lowest (USD 6,720) income and L2 had the highest (USD 60,317) (Table 4). This indicates that low intensity of fertilizer practices was not always about lack of capital for buying fertilizer.

No household relied on income from rubber alone; all diversified into different income sources, which varied depending on their capacity and opportunity. Rubber made up different portions of the different households' portfolios. Households in the $\mathrm{H}$ (Figure 6A) and M2 (Figure 6C) groups gained more than half of their income from rubber (58-64\%) and relatively high portions from remittances (17-18\%) compared to the other groups. This pattern also reflects the aging of the farmers in these groups. Other sources of income for these groups included engaging in wage labor, both farming and non-farming, and farming other crops such as cassava and vegetables, or raising animals on their own landholdings. Aging farmers also gained a small amount of money from an elderly subsistence allowance in almost every group.

It is interesting to note that overall, $21 \%$ of households relied on rubber income and the elderly subsistence allowance and/or remittances, and that these households were in the $H, M 1$, and M2 groups, particularly the $\mathrm{H}$ group. For these households, income from rubber made up, on average, $72 \%$ of their income, indicating their vulnerability to decreasing rubber prices and increasing production costs.

The most diversified income households in this study were the M1 households, where rubber represented only $39 \%$ of total household income. For this group, permanent non-farm jobs in the area were the second most important source of income, followed by remittances, crop diversification, and other occasional non-farm jobs (Figure 6B).

In the L1 households, with relatively older farmers (64 years old), remittances only accounted for $2 \%$ of household income while rubber made up about $50 \%$, indicating their high dependence on rubber. Moreover, these aged farmers provided most of their own labor. Their other income sources were from hiring themselves out as labor at other farms, permanent non-farm jobs, and a small amount of crop diversification (Figure 6D). The single farmer in the last group, L2, was a local government employee who gained $59 \%$ of the household's income from that job, while rubber and land rental were supplementary sources of income (Figure 6E). 


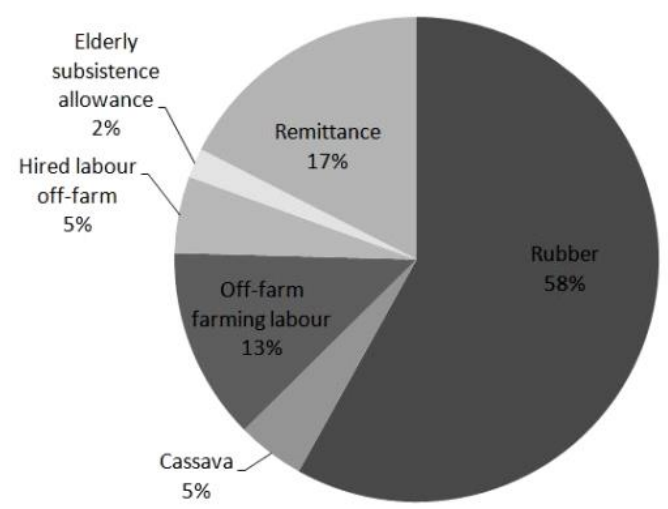

(A)

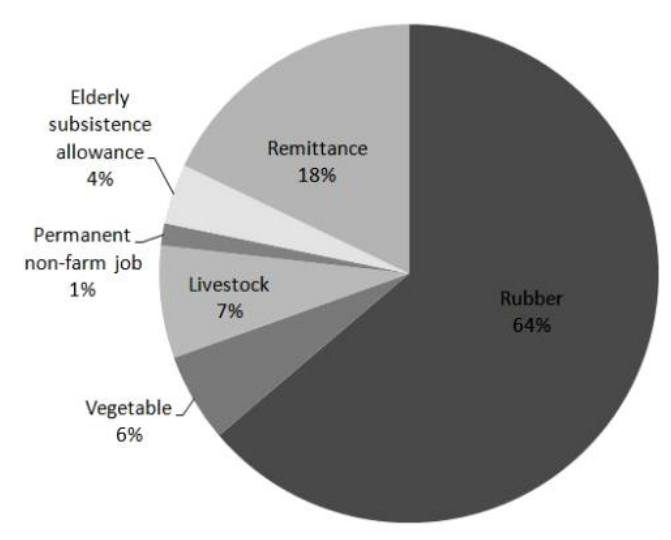

(C)

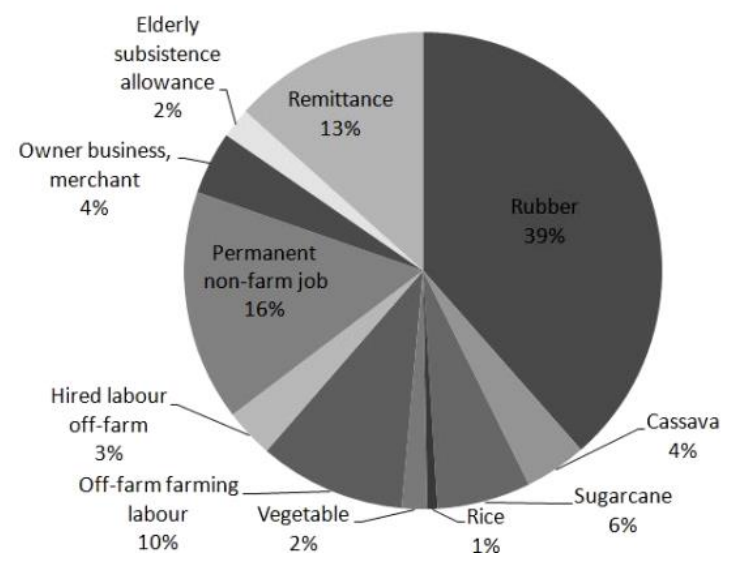

(B)

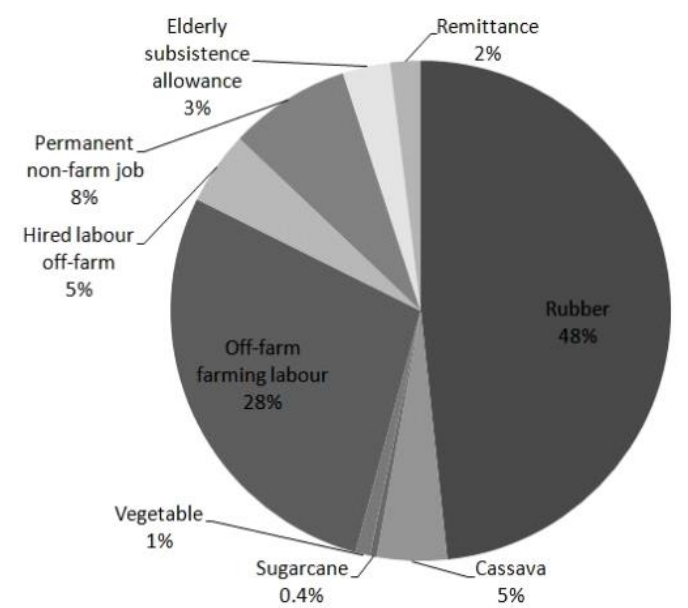

(D)

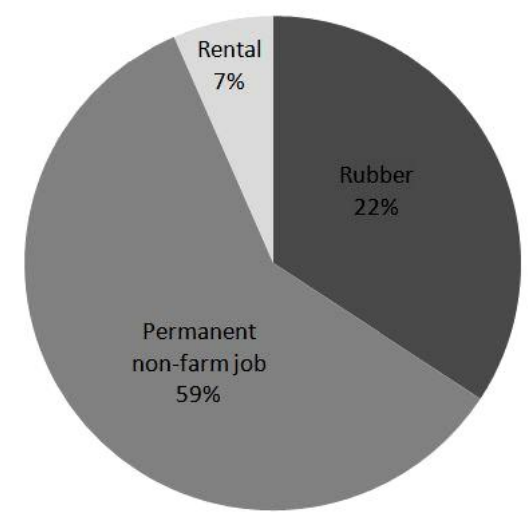

(E)

Figure 6. Source of income of rubber farmer households at three intensity levels of fertilizer practices in the study site: (A) high intensity (H); (B) medium intensity/family labor (M1); (C) medium intensity/hired labor (M2); (D) low intensity/family labor(L1); (E) low intensity/hired labor(L2). Income from rubber was calculated as income from 10-13 year old rubber plots. 


\section{Discussion}

This study's results show that, during the period of low rubber prices that began in 2012, all of the farmers in the study site continued to use fertilizers, and most of them (the $\mathrm{H}$ and $\mathrm{M}$ groups, $86 \%$ of our sample) used rather high quantities of it. The farmers in the $\mathrm{H}$ and $\mathrm{M}$ groups used chemical fertilizer alone, which supplied nutrients at rates of $82.0-137.6 \mathrm{~kg} / \mathrm{ha} / \mathrm{y}$ of $\mathrm{N}, 33.3-97.7$ $\mathrm{kg} / \mathrm{ha} / \mathrm{y}$ of $\mathrm{P}_{2} \mathrm{O}_{5}$, and $30.1-69.3 \mathrm{~kg} / \mathrm{ha} / \mathrm{y}$ of $\mathrm{K}_{2} \mathrm{O}$. These rates for $\mathrm{N}$ and $\mathrm{P}_{2} \mathrm{O}_{5}$ are consistent with the RAOT recommendations for mature rubber plantations $(75-150 \mathrm{~kg} / \mathrm{ha} / \mathrm{y}$ of N, 25-50 kg/ha/y of $\mathrm{P}_{2} \mathrm{O}_{5}, 90-120 \mathrm{~kg} / \mathrm{ha} / \mathrm{y}$ of $\mathrm{K}_{2} \mathrm{O}$; Kangpichadan, 2009). Chambon et al. (2018), however, argue that these rates are high when compared to the rates recommended in other countries. They are also higher than the average rubber nutrient requirement of 1-25 year old rubber trees $(68-8-45 \mathrm{~kg} / \mathrm{ha} / \mathrm{y}$ of $\mathrm{N}-\mathrm{P}_{2} \mathrm{O}_{5}-\mathrm{K}_{2} \mathrm{O}$ ), as measured in different parts of Thailand (Yingjajaval \& Bangjan, 2006). The finding of high levels of input of chemical fertilizer in this study confirms the findings reported in the studies of Chambon et al. (2018) and Wimalagunasekara et al. (2012) that in areas where farmers did not historically grow rubber, that farmers use more chemical fertilizer than necessary.

The intensive use of fertilizer found in the current study, however, differs from the report of a previous study conducted in the same region. Neadkhun (2017) indicated that, in the context of low rubber prices, farmers decreased chemical and organic fertilizer use in their rubber plots by about $50 \%$, as well as reduced the frequency of fertilizer application from two times a year to one time a year, and even stopped applying fertilizer in some cases. The difference may be partly due to the geo-physical characteristics of the study village, as the current study's site is more marginal for rubber, with lower rainfall and soil fertility. The high rate of fertilizer use found in this study is also not consistent with the results of Somboonsuke et al.'s (2018) field surveys of 2,971 RAOT-supported farmers across the country; they reported that one of the main production problems of Thai rubber farmers was under-use of chemical fertilizers compared to RAOT's recommended rates. However, Somboonsuke et al. (2018) did not report precise $\mathrm{N}-\mathrm{P}_{2} \mathrm{O}_{5}-\mathrm{K}_{2} \mathrm{O}$ rates, particularly in mature plantations. In addition, the current study's finding of high use of fertilizer in this marginal area in the context of low prices contradicts an earlier finding of lower fertilizer use for rice by farmers in the same region (Rigg, 1985). The main difference in this case may be that rubber is a perennial and rice an annual crop.

Organic fertilizer accounted for $65 \%$ of the fertilizer cost for the medium intensity groups (Figure 5). All fertilizer accounted for $50 \%$ and $45 \%$ of the total cash production costs in the high and medium groups, respectively (Table 3 ). These groups of farmers used about $9-21 \%$ of their annual income to pay for fertilizer, leading to low profits (Table 3 ). This finding indicates that during a period of low rubber prices, reducing fertilizer costs by lowering the amount used to the minimum requirement of rubber could increase farm incomes.

Zhang et al. (2015) reported that in northwest China, farmers could reduce the amount of chemical fertilizer used by up to $70 \%$ of their current use for maize, and up to $20 \%$ for wheat without affecting yields. They found that a $30 \%$ reduction in $\mathrm{N}$ use would increase household income by $2-$ $9 \%$, and a $50 \%$ reduction would increase it by $4-15 \%$, especially in poor households. However, in Thailand, to our knowledge, recommendations for different rates of fertilizer for rubber, depending on product price are not available. Furthermore, due to the perennial nature of the crop and the difference of the product from other crops-i.e., latex instead of fruit or grain-nutrient management is more complex. In fact, the yield response to fertilizer of rubber is generally low, as discussed in more detail below. Nevertheless, this study's results clearly show that the households that relied mainly on rubber spent a significant part of their incomes on fertilizer, expecting high returns. In general, smallholders do not consider themselves as a business unit focusing on profit, but rather consider the amount of money they will get after the harvest. This approach leads them to invest in production factors that they think will affect yield, an issue discussed further below. According to our interviews, the farmers' perception of fertilizer was that they needed to use it to 
get the latex. For instance, one farmer in the $\mathrm{H}$ group confirmed the importance of chemical fertilizer:

"Chemical fertilizer is very important. If I don't use it, I am afraid that the rubber will not give latex. When I use it, I feel that I get more latex."

At the same time, easy access to credit for fertilizer, both from farmers' groups and salesmen, may support the idea that increasing inputs leads to more income for these groups of farmers. Data from individual interviews show that most of the farmers got most of their fertilizer by using credit early in the rainy season, while they made cash purchases of small quantities later in the year when they thought more fertilizer should be applied.

We also found that farmers generally used their own experience as well as recommendations from fertilizer salesmen (Table 4) to adjust fertilizer rates in accordance with their attitudes and goals when the price of rubber was low. As one farmer explained:

"In the past, I used to get advice from other farmers who have experience, but now I investigate the rubber leaves as indicators. If there are too many leaves and they are dark green, it means that I used too much fertilizer. There will be competition between leaves and latex, and that will result in low latex yield."

This method of deciding on the fertilizer requirement of the crop through observation indicates that more precise but user-friendly methods for determining nutrient requirements at the field level are needed from the responsible organizations.

In the low fertilizer intensity group, the rate of nutrient application, based on chemical fertilizer application, was $35 \mathrm{~kg} / \mathrm{ha} / \mathrm{y}$ of $\mathrm{N}, 23 \mathrm{~kg} / \mathrm{ha} / \mathrm{y}$ of $\mathrm{P}_{2} \mathrm{O}_{5}$, and $8 \mathrm{~kg} / \mathrm{ha} / \mathrm{y}$ of $\mathrm{K}_{2} \mathrm{O}$. The farmers in this group had the lowest fertilizer cash cost (USD 134.6/ha/y), which accounted for $24 \%$ of their total production cash cost. Therefore, these farmers got higher gross added value (Table 3 ). The farmers in these groups reported that the reason they applied less fertilizer was that they had observed no significant increase in yield when they applied more. Such observations, however, may not be supported by recent research in Thailand, which found that the yield of fertilized rubber plots does not significantly increase until the third year of fertilization (Chotiphan et al., 2019), indicating that rubber has a delayed response to fertilizer. In India, fertilizer application has not been found to affect latex yield (Sherin \& Phebe, 2011). However, in Indonesia and Africa, Gohet et al. (2013) reported that a high rate of application of $\mathrm{N}$, at $100 \mathrm{~kg} / \mathrm{ha} / \mathrm{y}$, increased rubber yield by, on average, $10 \%$. With the declining price of rubber, our data suggest that using fertilizer to increase $\mathrm{N}$ to 100 $\mathrm{kg} / \mathrm{ha} / \mathrm{y}$, as in our high fertilizer intensity group, may not be a good strategy for household economy. While the farmers in the $\mathrm{H}$ group made some profit, it was relatively low compared to the profit made by the farmers in the lower intensity groups. It is also important to note that the application of high levels of nutrients in marginal environments such as this region may also cause unwanted environmental impacts on groundwater as well as pond and river pollution due to uncontrolled leaching. Excess application of fertilizer, particularly $\mathrm{N}$ and $\mathrm{P}_{2} \mathrm{O}_{5}$ causes environmental problems, and increases the potential for damaging aquatic ecosystems via eutrophication (Guignard et al., 2017).

Most of the farmers in our survey (16 out of 29) used a combination of chemical and organic fertilizers, and some (8 out of 29) had switched from chemical fertilizer to organic fertilizer. Making a change from chemical to organic fertilizer or a combination of both types is an important recommendation, which the government encourages farmers to do when rubber prices are low. However, the government does not provide clear information on how much or what quality of organic fertilizer should be applied. 


\section{Conclusions}

Our results showed that when rubber prices were low, all groups of farmers suffered. Farmers adjusted their fertilizer use to reduce production costs by reducing the amount of chemical fertilizers they bought, switching to lower-cost brands of chemical fertilizer, switching to organic fertilizer, or combining organic and chemical fertilizers. However, we found that even after they decreased their fertilizer use, most of the rubber farmers (86\%) still over-used chemical fertilizer, supplying more than necessary amounts of nitrogen and phosphorus in particular with possible negative impact on the environment. At the same time, many of the farmers followed the recommendation to lower their fertilizer costs by turning to commercial organic fertilizer, both by combining it with chemical fertilizer or using organic fertilizer alone in substantial amounts, while not knowing how much of the different nutrients these fertilizers supplied. These patterns led to higher production costs, in which fertilizer might account for $45-50 \%$ of the farmers' total production cash cost, leading to the low profitability of rubber. Therefore, there is an urgent need for scientists to analyze the economic viability of organic fertilizer use. Their findings will enable the responsible institutions in Thailand to provide recommendations for its use, whether alone or in combination with chemical fertilizer. Planners need to identify optimal recommendations for fertilization practices for sustaining the growth and yield of rubber, limiting possible environmental externalities, and protecting the incomes of rubber-producing farming households. Policy makers must base strategic policy on fertilizer experiments conducted in different locations under different bio-physical conditions, at the same time taking into account the diversity of farmer characteristics and goals. When policy makers provide clear fertilizer recommendations under different price scenarios, and provide better fertilizer management information to rubber farmers, they would not need to choose their fertilization practices based on their feelings or the advice of fertilizer salespersons. Better information on the fertilizer requirements of rubber would help farm households that grow rubber avoid wasting money on unnecessary fertilizer and improve the longterm sustainability of their rubber farms. At the same time, such policies will enable farmers to grow rubber trees that sustain and increase the economic, social and environmental values, for the benefit of present and future generations.

Author Contributions: S.K., S.A., B.C. and A.P. conceptualization; S.K., S.A., B.C. and A.P. methodology; S.K. investigation; S.K. writing-original draft preparation; S.K., S.A., B.C. and A.P. writing-review and editing; A.P. supervision.

Conflicts of Interest: The authors declare no conflict of interest.

\section{Acknowledgments}

This research was funded by the Graduate School, Khon Kaen University, and Jeunes Equipes Associées à l'IRD program (JEAI), a co-program of IRD, France and Khon Kaen University, Thailand. The authors would like to thank all participating rubber farmers and officers in the study site for their hospitality and full support. The authors very much appreciated the manuscript review and suggestions offered by Dr. Russell Yost of the University of Hawai'i at Mānoa, and Dr. Jefferson Fox of the East-West Center, Honolulu, Hawai'i.

\section{References}

Agricultural research development agency (public organization). (n.d.). Rubber industry and production technology. Retrieved from http://www.arda.or.th/kasetinfo/south/para/used/0102.php 
Burannasarn, C., Aditto, S., \& Sriwaranun, Y. (2015). Production and marketing management of cup lump para rubber farmers in Ban Kruat district, Buriram province. Khon Kaen Agriculture Journal, 43(suppl. 1), 734-737.

Chambon, B., Dao, X. L., Tongkaemkaew, U., \& Gay, F. (2018). What determine smallholders' fertilization practices during the mature period of rubber plantations in Thailand? Experimental Agriculture, 54(6), 824-841.doi: https://doi.org/10.1017/S0014479717000400

Chambon, B., Ruf, F., Kongmanee, C., \& Angthong, S. (2016). Can the cocoa cycle model explain the continuous growth of the rubber (Hevea brasiliensis) sector for more than a century in Thailand?. Journal of Rural Studies, 44, 187-197. doi: https://doi.org/10.1016/j.jrurstud.2016.02.003

Chotiphan, R., Vaysse, L., Lacote, R., Gohet, E., Thaler, P., Sajjaphan, K., Bottier, C., Char, C., Liengprayoon, S., \& Gay, F. (2019). Can fertilization be a driver of rubber plantation intensification? Industrial Crops Production, 141, 1-11. doi: https://doi.org/10.1016/j.indcrop.2019.111813

Department of Agricultural Extension. (2012). Farmer Map Report 2012. Retrieved from http://farmer.doae.go.th/index.php/bi_report/bi_report5

Fox, J., \& Castella, J. C. (2013). Expansion of Rubber (Hevea brasiliensis) in Mainland Southeast Asia: What are the Prospects for Small Holders? Journal of Peasant Studies, 40(1), 155-170. doi: https://doi.org/10.1080/03066150.2012.750605

Gohet, E., Saaban, I., Soumahoro, M., Uche, E., Soumahoro, B., \& Cauchy, T. (2013, November 19). Sustainable rubber production through good latex harvesting practices: An update on mature rubber fertilization effects on latex cell biochemistry and rubber yield potential. In IRRDB Workshop on Latex Harvesting Technology. IRRDB Workshop on Latex Harvesting Technology, Binh Duong, Vietnam. https://doi.org/10.13140/RG.2.1.5147.6004

Guignard, M. S., Leitch, A. R., Acquisti, C., Eizaguirre, C., Elser, J., Hessen, D. O., Jeyasingh, P. D., Neiman, M., Richardson, A. E., Soltis, P. S., Soltis, D. E., Stevens, C. J., Trimmer, M., Weider, L. J., Woodward, G., \& Leitch, I. J. (2017). Impacts of Nitrogen and Phosphorus: From Genomes to Natural Ecosystems and Agriculture. Frontiers in Ecological Evolution, 5, 1-9. doi:https://doi.org/10.3389/fevo.2017.00070

Hurni, K., \& Fox, J. (2018). The expansion of tree-based boom crops in mainland Southeast Asia: 2001 to 2014. Journal of Land Use Science, 13(1-2), 198-219. doi: https://doi.org/10.1080/1747423X.2018.1499830

Kangpichadan, N. (2009). Recommendation for rubber fertilizer. Rubber Research Institute, Department of Agriculture, Ministry of Agriculture and Cooperatives.

Kullawong, S., Aditto, S., Chambon, B., \& Promkhambut, A. (2018). Dynamic of rubber production in Northeast Thailand; a case study at Subsomboom village, Doonsard sub-district, Kranuan district, Khon Kaen province. Khon Kaen Agriculture Journal, 46 (suppl. 1), 239-248. https://ag2.kku.ac.th/kaj/PDF.cfm?filename=039\%20Ext30.pdf\&id=3015\&keeptrack=0

Land Development Department. (2015). GIS soil map information. Retrieved from http://gisinfo.Idd.go.th/cd_land_map.html?land_type=LAND_SOIL\&province_id=040\&amphu r_id=04009\&tambol_id=0400909\&zoom $=\{\% 22$ zoom\%22:1,\%22position\%22: $\% 22$ posX\%22:0, $\% 22$ posY\%22:0\}\}

Neadkhun, P. (2017). Coping a strategies against decline and fluctuation of rubber price by smallholder farmers in Northeast Thailand: Nonsa, Kokkong sub-district, Muang district, Bangkan province [Master of Science Thesis in System Approaches in Agriculture]. Graduate School, Khon Kaen University.

Nicod, T. (2017). Etude sur les stratégies d'adaptation des petits planteurs d'hévéa Thaïlandais, face à la chute du prix du caoutchouc naturel [Final thesis: Intership in Thailand within the HEVEADAPT program with CIRAD and Khon Kaen University partnership]. College of International Agro-Development, ISTOM. 
Rigg, D. J. (1985). The Role of the Environment in Limiting the Adoption of New Rice Technology in Northeastern Thailand. Transactions of the Institute of British Geographers, 10(4), 481-494. doi: https://doi.org/10.2307/621893

Royal Forest Department. (n.d.). Executive summary of forestry database project. Retrieved from http://forestinfo.forest.go.th/Content/file/executive-summary-2561.pdf

Rubber Research Institute of Thailand, Department of Agriculture. (n.d.). Agriculture News. Retrieved from http://www.raot.co.th/ewt_w3c/ewt_dl_link.php?nid=2950

Rubber Research Institute of Thailand, Department of Agriculture. (2011). Fertilizer recomendations for rubber. The Agricultural Cooperative Federation of Thailand., Ltd.

Sherin, G., \& Phebe, J. (2011). Natural rubber plantation: A nutritionally self-sustaining ecosystem. Natural Rubber Research, 24(2), 197-202.

Somboonsuke, B., Kongmanee, C., Thongtrai, N., \& Phitthayaphinant, P. (2018). Potential of pararubber production in Thailand: Production technology management, problems and suggestions for yield improvement. Kasetsart Journal of Social Sciences, 39, 645-659.

Thailand, Doonsard Subdistrict Administrative Organization. (2016). Report of community development plan: Subsomboon village 2016 (pp. 1-3). Department of Local Administration, Ministry of Interior, Thailand.

Thongpan, S. (2016). The history of rubber in Southeast Asia and the Mekong subregion: Changes in geographical locations of supply and demands. Journal of Mekong Societies, 12(2), 187-214.

Tongkaemkaew, U. (2013). Rubber Plantation in Northeast Thailand: Sources of Labors and Characteristics of Plantation Owners, and Its Impacts on Income and Living Status of Local Owners and Full-time Hired Labors [Doctor of Philosophy Thesis in Systems Agriculture]. Graduate School, Khon Kaen University.

Tongkaemkaew, U., \& Patanothai, A. (2013). Expansion of rubber plantations in Northeast Thailand: Income and living status of full-time hired labors. Khon Kaen Agriculture Journal, 41(4), 497506.

Viswanathan, P. K. (2008). Emerging Smallholder Rubber Farming Systems in India and Thailand: A Comparative Economic Analysis. Asian Journal of Agriculture and Development, 5(1362-2016107697), 1-19. doi: https://doi.org/10.22004/ag.econ.198984

Wimalagunasekara, T. U., Edirisinghe, J. C., \& Wijesuriya, W. (2012). Neighbours' Influence on Farmer Adoption of Fertiliser Recommendations in Rubber Cultivation. Journal of Rubber Research, 15(3), 179-186.

Yingjajaval, S., \& Bangjan, J. (2006). Major Plant Nutrient Contense in Para Rubber (RRIM 600). Agricultural Science Journal (Thailand), 37(4), 353-364.

Zhang, S., Gao, P., Tong, Y., Norse, D., Lu, Y., \& Powlson, D. (2015). Overcoming nitrogen fertilizer over-use through technical and advisory approaches: A case study from Shaanxi Province, northwest China. Agriculture, Ecosystems \& Environment, 209(1), 89-99. doi: https://doi.org/10.1016/j.agee.2015.03.002 